\title{
STUDIA

\section{Axiological principles of integrated protection of human and natural environments}

\section{Aksjologiczne podstawy integralnej ochrony środowiska przyrodniczego i ludzkiego}

\section{Wojciech Bołoz}

Institute of Ecology and Bioethics, Cardinal Stefan Wyszyński University in Warsaw, Poland

\begin{abstract}
Over the last few decades, we have witnessed a significant change in human mentality and attitudes towards the natural environment and its protection. This change is accompanied by different axiological principles within which we can distinguish: 1) the anthropocentric concept which places man in the centre and grants him a privileged place amongst other species; 2) the anti-anthropocentric concept which stresses the equality of all species and demands a reversal in humanistic orientation consolidated by the European Enlightenment; 3 ) the moderate anthropocentric concept which underlines human's caring and a responsible role towards THE ecosystem. As disturbances of ecological balance are the result of human actions and the sign of the cultural crisis, the necessity to protect the natural environment should be realised. John Paul II was a supporter of the above. He referred to the integrated ecology, which combines the protection of the natural environment with the concern of the quality of human spirituality. Integrated ecology poses two demands: 1) all actions towards environmental protection should be understood as means of confirming the respect of human personal dignity; 2) those actions which harm the natural environment and threaten man should be given up.
\end{abstract}

Keywords: anthropocentrism, biocentrism, moderate anthropocentrism, human rights, human dignity

Streszczenie: W ciągu ostatnich dekad jesteśmy świadkami znaczącej zmiany w mentalności ludzi i ich stosunku do środowiska naturalnego i jego ochrony. Zmianie tej towarzyszą różne zasady aksjologiczne, wśród których można wyróżnić: 1) koncepcję antropocentryczną, która w centrum stawia człowieka i przyznaje mu uprzywilejowane miejsce wśród innych gatunków; 2) koncepcję anty-antropocentryczną, która akcentuje równość gatunków i domaga się odwrócenia orientacji humanistycznej ugruntowanej przez europejskie oświecenie; 3) koncepcję umiarkowanie antropocentryczną, która podkreśla ludzką troskę i odpowiedzialność wobec ekosystemu. Ponieważ zaburzenia równowagi ekologicznej jest skutkiem działania człowieka i znakiem kryzysu kulturowego, konieczne jest uświadomienie sobie potrzeby ochrony środowiska naturalnego. Głosił to papież Jan Paweł II, odwołując się do ekologii integralnej, która łączy ochronę środowiska naturalnego i troskę o jakość duchowego życia człowieka. Ekologia integralna stawia dwa wymagania: 1) wszystkie działania na rzecz ochrony środowiska powinny być rozumiane jako środki umocnienia szacunku dla godności człowieka; 2) należy porzucić to wszystko, co niszczy środowisko naturalne i zagraża człowiekowi.

Słowa kluczowe: antropocentryzm, biocentryzm, antropocentryzm umiarkowany, prawa człowieka, godność osoby

"This article was originally published in Polish as Bołoz, Wojciech. 2006. "Aksjologiczne podstawy integralnej ochrony środowiska przyrodniczego i ludzkiego." Studia Ecologiae et Bioethicae 4: 113-120. The translation of the article into English was financed by the Ministry of Science and Higher Education of the Republic of Poland as part of the activities promoting science - Decision No. 676/P-DUN/2019 of 2 April 2019. Translation made by GROY Translations. 


\section{Introduction}

In 1972, the first UN and UNESCO Conference on the Protection of the Environment took place in Stockholm, where the Environment Protection Code was adopted, and the day of 5th June was declared the Environment Day. In the same year, the Club of Rome's Report The Limits to Growth was published, in which a team led by Dennis Meadows predicted the depletion of natural resources and reduction in food production and, as a result, a large decrease in population in the future. These events aroused great interest and constituted a turning point in the international debate concerning the subject of attitude towards nature. Although, fortunately, the future has not confirmed the pessimistic predictions of the Club of Rome, greater attention has been paid to human activity causing contamination of soil, water and air and the resulting damages, which have been followed by a serious balance disturbance in the natural environment. The population of large areas in different countries of the world has been living in areas of ecological threat. Under the influence of negative phenomena caused by pollution of the environment, concern for its improvement has been placed in the spotlight of world public opinion (Muszyński 1999, 472).

Under the influence of growing interest in ecological issues, the concept of 'sustainable development' has been established which consists of achieving the prosperity of the current generation in such a way as to guarantee the same aspirations for the next generations. The sustainable development strategy means environmental protection, reasonable management of natural resources, fair distribution of the benefits resulting from economic growth, changing unreasonable consumption patterns and social development, especially access to education, health protection and equal opportunities. A significant element of the sustainable development is environmental protection, but this concept also implies protection and development of the human environment.

\section{Differentiated axiology of the protection of the natural environment}

All activities related to the protection of the environment are preceded by conscious or unconscious axiological assumptions, which are expressed in such a way that (1) particular values are recognised as the values of paramount importance which constitute the basis for standards and assessments, (2) those values are indicated which favour the formation of pro-ecological attitudes promoting the natural environment (Tyburski 1999, 155). These axiological assumptions are mainly connected with three concepts, which will be further briefly discussed.

\section{a) The anthropocentric concept of the protection of the natural environment}

This concept is based on the assumption that human being is the highest link in evolution and for this reason, it occupies a central place in the world. As it is the only rational and autonomous being among all mammals, therefore it is exclusively entitled to the status of a person, a specific value called dignity and human rights that protect it. This model of relations between man and nature has functioned properly in the Western world for thousands of years. Only when the enormous damage to the natural environment occurred in the 20th century, people have started to look for reasons for this situation. There was a view that this was the consequence of an unequal relationship between man and nature, based on the exploitation of the ecosphere, which consequently led to its contamination. The authors Lynn White Jr. (White 1967, 1203-1207) and Carl Amery (Amery 1972, 10-11) have begun to propagate the view that the biblical anthropocentrism expressed in the precept of Genesis: 'Be fruitful and increase in number; fill the earth and subdue it. Rule over the fish in the sea and the birds in the sky and over every living creature that moves on the ground.' (Gen 1:28), resulted in the Judeo-Christian tradition of objectifying nature and making the inhabitants of the West exploit it. According to them, the 
traditional anthropocentric ethics are the ethics of standards regulating human behaviour towards people, which do not protect other creatures.

However, supporters of the view that Judaism and Christianity are responsible for the environmental crisis forget that the Bible does give man, created in the image of God, a privileged place and a role in the world, but also orders him to take care of it. Man's domination of the world means not only the right to use its resources for his own purposes but also responsibility for its present and future.

\section{b) The anti-anthropocentric concept}

Representatives of this concept claim that traditional ethics is anthropocentric; by focusing on man, it is unable to save the world from destroying the ecosystem. Meanwhile, the world is a place of human life, and that is why it must be secured. In order to do so, it is important to abandon the current anthropocentric ethics in favour of the Earth's ethics. Its founder was Aldo Leopold (1887-1948), Professor at the University of Wisconsin in Madison. This ethics assumes biocentric equality of all species, which grants the same rights to animals and plants as to man. Moreover, because of the existing exploitation of nature by a human being, the latter should have fewer rights than other participants of the global ecosystem. Aldo Leopold used the following wording: Earth, plants, animals have rights, man has duties. To protect other species from man, it is necessary to guarantee zero growth of the human species (Bołoz 2003, 165). This concept has become an element of so-called deep ecology, which was first described by A. Naess in 1973. This concept demands a change in the paradigm of the dominant culture and a limitation of human control over other species and, as a consequence, treating man only 'as a particle of an organic whole' and, as a consequence, the above-mentioned biocentric equality (Devall i Sessions 1994, 94n).

According to the representatives of deep ecology, the European Enlightenment with the French Declaration of Human Rights (1789) is a particular manifestation of a dominant, humanist-oriented culture. In the opinion of the supporters of bio-equality, they have brought "unfortunate consequences" because they have consolidated a humanist perspective in the world. Therefore, a fundamental reorientation is required: recognition of the legal capacity of nature, plants and animals. In this way, nature would have guaranteed rights that it could pursue through its curators or proxies, as it happens in the case of infants (Sobański 1998, 199).

\section{c) The concepts of moderate anthropocentrism}

The moderate anthropocentrism recognises the own value of all species, but gives a special place to human beings, because only they can take rational, planned actions, only they can save themselves and other species from extinction. Taking away man's central place in the world, equating him with other species and, above all, depriving him of his rights granted to the human being would only seemingly be a victory for the environment and ecology. Human beings reduced to the level of other mammals, deprived of moral responsibility and conscience, would be a threat to other species. Examples indicating this possibility can be found in history. Anthropocentrism does mean a higher status of man among other creatures, but it also makes him feel a moral subject obliged to behave rationally and responsibly in the world.

This protective function of man in relation to the world results quite clearly from biblical statements: 'Yahweh God took the man, and put him into the Garden of Eden to dress it and to keep it' (Gen 2:15) (Häring 1981, 199). The role of the 'Gardener of Eden' received from the Creator can also be interpreted as a task to continue the creation. Therefore, there is no consent in the Bible to man's unlimited dominance over the world, but there is an encouragement to care for it and to take responsibility for life on earth (Ślipko 1994, 27n; 
Grzesica 1983). The human being cannot share this responsibility for the ecosystem with any other species for this simple reason, because its condition is a rationality that is specific only to humans. Ecological fundamentalism, by declaring biocentric equality, brings man down to the level of plants and animals, and thus relieves him of moral responsibility. Meanwhile, each level of ecological reality corresponds to its own axiological status. Therefore, there can be no question of the absolute value of human being or any other species (Viafora 2002, 615). 'Every living creature is its own goal, which does not require further justification. In this respect, a human being is in no way superior to other living beings except that only he can bear responsibility for them as well, which means protecting them as a goal for himself" (Jonas 1990, 181). Therefore, it is not biology that leads people to limit themselves and relativise their own interests, but respect for their own dignity and the dignity of all other people, also future generations, who have a right to a healthy natural environment.

Therefore, the road to a solution to the ecological issue does not lead to a lowering of the status of man in the world, but to the appreciation of the world of plants and animals as a carrier of self-esteem independent from man, without, however, bringing them up to the level of a legal and moral entity, because they cannot accept this attribute. Only man can make moral judgements, thanks to which one can speak of the value of the environment and demands its protection' (Sobański 1998, 328).

\section{The need for protection of the human environment}

In 1866, biologist Ernst Haeckel (18341919), professor of the University of Jena and German enthusiast and promoter of Charles Darwin's theory, introduced the term ecology originating from the Greek word oikos (house, farm, dwelling). 'Ecology is the knowledge of the relationships between an organism and the environment' (Kalinowska 1991, 13). This term takes into account the natural environment and its protection against contamination of water, soil, plants and animals as well as the landscape. However, this concept demands to be extended to other dimensions of the environment, because the natural environment is not the only one which determines the quality of human life. The disturbance of the balance of the earth's living environment is the effect of human action and a symptom of a cultural crisis. Therefore, remedies must not be limited solely to actions aimed at protecting the natural environment. It is also necessary to heal human awareness and renew culture.

John Paul II shows a realistic way to restore human solidarity with nature. His concept can be called the concept of integrated ecology, because it combines the need to protect the natural environment with the need to care for the spiritual environment of a human being. He believes that at the roots of the irrational destruction of the natural environment lies the anthropological error that is widespread in our times. "Man believes that he can freely dispose of the earth, subordinating it to his own absolute will, as if it has no shape of its own and no previous destiny, designated to it by God, which man, of course, can develop but which he cannot misappropriate" (John Paul II 1991, no. 37). Such conduct, caused by a desire for possession, finally provokes a rebellion of nature that is not so much ruled as tyrannised by man.

However, it is not enough just to care for the balance of the ecosystem by protecting endangered plant and animal species. The human environment also demands protection. 'Not only has the earth been given to man by God to be used with respect for the original intended good for which it was given to him, but man is also a gift to himself received from God and therefore he must respect the natural and moral structure with which he is equipped' (John Paul II 1991, no. 38). It seems that the term 'human ecology', or 'man ecology', which the Pope often uses, refers to the conditions of social life, and takes into account those human relationships which guarantee respect for everyone's dignity and en- 
able everyone to live in freedom and truth (John Paul II. 1995, no. 42).

The human environment is shaped by the following four factors. These are:

a) The environment variable: the physical environment (non-renewable resources such as minerals, earth energy, water, air) and the plant and animal environment $t$, which constitute the whole of renewable natural resources.

b) The demographic variable: demographic dynamics, population distribution in the territory, creation of urban and industrial agglomerations; changes caused by urbanisation and other human activities: noise, radiation from electromagnetic fields, exposure to allergens.

c) The technological variable: energy use, information and communication technologies, biotechnology related to the life of plants, animals and humans. In this context, the human biological structure is particularly important and we want to protect it from irresponsible interference.

d) The ethical and social variable: social relations and behaviour, morality, culture and institutions, in particular, the family; individual and social responsibility for the state of nature' (Barbieri Masieni 2001, 550). In human being and his interpersonal relationships, there is the cause of environmental risks and the key to solving them' (Mariański 1993, 165-184).

Each of these variables is conditioned by assumptions and actions at general, local and personal level. None of these areas can be completely isolated. However, as global and macro-environmental ecological activities face enormous difficulties, the greater is the significance of local initiatives, small and large communities, which should take such actions as to create a beneficial natural and human environment for their inhabitants.

\section{Human right to the environment}

Ethics can only be discussed in the context of the human being. The human being is also subject to rights and obligations. Although man grows above the material and biological world, he is nonetheless an element of the ecosphere, and therefore actions which destroy nature and the natural environment lead in consequence to human degradation. For this reason, environmental ethics formulates a double demand (Łukomski 1999, 185):

1. any actions aimed at protecting the environment should be understood as an expression of respect for human dignity;

2. all actions which harm the environment and reduce the quality of human life should be abandoned.

In Stockholm in 1972, at the end of the above-mentioned $1^{\text {st }}$ United Nations Conference on the Human Environment, a Declaration was adopted, in which we read: "Man has the fundamental right to freedom, equality and appropriate living conditions in an environment of quality which allows him to live in dignity and well-being. At the same time, he bears a solemn responsibility to protect and improve the environment for present and future generations" (Kocot, i Wolfke 1978, 581-588). This wording assumes that 'An appropriate environment is a prerequisite for the exercise of all human rights, including the right to live' (Radecki 1987, 12). This human right to the environment may be interpreted differently: 1 ) as a demand for the protection of the environment, 2) as a right to live in an environment which provides a decent living, 3) as a right to benefit from the values of the environment (Sobański 1998, 318).

This right to the environment does not only mean the right to the natural environment. The condition for the exercise of human rights is also to guarantee an adequate human environment which guarantees the development of the human spirit and a high level of culture.

\section{Bibliography}

Amery, Carl. 1972. Das Ende der Vorsehung. Die gnadenlosen Folgen des Christentums. Hamburg: Rowohlt Verlag GmbH. 
Barbieri, Eleonora. 2001. „Zasada ekologii ludzkiej." Społeczeństwo 5: 549-558.

Bołoz, Wojciech. 2003. „Bioetyka. Jej historia i sposoby ujmowania." Studia Ecologiae et Bioeticae 1: 161-175.

Devall, Bill, i George T. Sessions. 1994. Ekologia gtęboka: żyć w przekonaniu, iż Natura coś znaczy. Warszawa: Wydawnictwo Pusty Obłok.

Grzesica, Jan. 1983. Ochrona naturalnego środowiska człowieka - problem teologiczno-moralny. Katowice: Księgarnia Świętego Jacka.

Häring, Bernhard. 1981. Frei in Christus: Moraltheologie für die Praxis des christlichen Lebens, Bd II. Freiburg-Basel-Wien: Verlag Herder.

John Paul II. 1991. Encyclical Letter «Centesimus annus». Rome: Libreria Editrice Vaticana.

John Paul II. 1995. Encyclical Letter «Evangelium vitae». Rome: Libreria Editrice Vaticana.

Jonas, Hans. 1990. Zasada odpowiedzialności. Etyka dla cywilizacji technologicznej. Kraków: Platan.

Kalinowska, Anna. 1991. Ekologia: wybór przyszłości. Warszawa: Editions Spotkania.

Kocot, Kazimierz, i Karol Wolfke (red.). 1978. Wybór dokumentów do nauki prawa międzynarodowego. Wrocław-Warszawa: Wydawnictwo Naukowe PWN.

Łukomski, Julisław. 1999. „Podstawy chrześcijańskiej etyki środowiska naturalnego." W Ochrona środowiska w filozofii $i$ teologii, red. Józef M. Dołęga, Jacek W. Czartoszewski, 177-202. Warszawa: ATK.
Mariański, Janusz. 1993. „Kwestia ekologiczna w encyklice «Centesimus annus»", Colloquium Salutis 25: 165-184.

Muszyński, Zygmunt. 1999. „Środowisko i zdrowie." W Kompendium wiedzy o ekologii, red. Jan Strzałko, i Teresa Mossor-Pietraszewska, 472-512. Warszawa: Wydawnictwo Naukowe PWN.

Radecki, Wojciech. 1987. „Filozoficzne i polityczne podstawy prawa człowieka do środowiska." W Prawo człowieka do środowiska naturalnego, red. Jerzy Sommer, 10-26. Wrocław: Zakład Narodowy im. Ossolińskich.

Sobański, Remigiusz. 1998. „Prawa człowieka a ekologia." W Prawa człowieka w państwie ekologicznym, red. Remigiusz Sobański, 301347. Warszawa: Wydawnictwo ATK.

Ślipko, Tadeusz. 1994. Granice życia. Dylematy wspótczesnej bioetyki. Kraków: WAM.

Tyburski, Włodzimierz. 1999. „Aksjologia ochrony środowiska przyrodniczego." W Ochrona środowiska $w$ filozofii $i$ teologii, red. Józef M. Dołęga, i Jacek W. Czartoszewski, 153-169. Warszawa: Wydawnictwo ATK.

Viafora, Corrado. 2002. „Niepodzielna godność. Analiza bioetycznych implikacji Karty praw podstawowych Unii Europejskiej." Spoteczeństwo 5: 615-617.

White, Lynn Jr. 1967. "The Historical Roots of our Ecologic Crisis." Science 155: 1203-1207. 